\title{
Estrogen receptor $\beta 2$ and $\beta 5$ are associated with poor prognosis in prostate cancer, and promote cancer cell migration and invasion
}

\author{
Yuet-Kin Leung 1,3,4, Hung-Ming Lam ${ }^{1}$, Shulin W ${ }^{5}$, Dan Song ${ }^{1}$, \\ Linda Levin', Liang Cheng ${ }^{6}$, Chin-Lee W $u^{5}$ and Shuk-Mei Ho ${ }^{1,3,4}$
}

\begin{abstract}
${ }^{1}$ Division of Environmental Genetics and Molecular Toxicology, Department of Environmental Health, ${ }^{2}$ Division of Epidemiology and Biostatistics, Department of Environmental Health, ${ }^{3}$ Center for Environmental Genetics and ${ }^{4}$ Cancer Center, College of Medicine, University of Cincinnati Medical Center, Cincinnati, Ohio 45267, USA

${ }^{5}$ Department of Pathology, Massachusetts General Hospital and Harvard Medical School, Boston, Massachusetts 02114, USA

${ }^{6}$ Department of Pathology and Laboratory Medicine, Indiana University, Indianapolis, Indiana 46202, USA

(Correspondence should be addressed to S-M Ho at Division of Environmental Genetics and Molecular Toxicology, Department of Environmental Health, College of Medicine, University of Cincinnati Medical Center; Email: shuk-mei.ho@uc.edu)
\end{abstract}

\begin{abstract}
Estrogens play a pivotal role in the development and progression of prostate cancer (PCa). Their actions are mediated by estrogen receptors (ERs), particularly ER $\beta$ in the prostate epithelium. With the discovery of ER $\beta$ isoforms, data from previous studies that focused principally on the wild-type ER $\beta$ (ER $\beta 1$ ) may not be adequate in explaining the still controversial role of ER $\beta(s)$ in prostate carcinogenesis. In this study, using newly generated isoform-specific antibodies, immunohistochemistry $(\mathrm{IHC})$ was performed on a tumor microarray comprised of 144 specimens. IHC results were correlated with pathological and clinical follow-up data to delineate the distinct roles of ER $\beta 1$, $\mathrm{ER} \beta 2$, and ER $\beta 5$ in PCa. ER $\beta 2$ was commonly found in the cytoplasm and was the most abundant isoform followed by ER $\beta 1$ localized predominantly in the nucleus, and ER $\beta 5$ was primarily located in the cytoplasm. Logistic regression analyses demonstrated that nuclear ER $\beta 2$ (nER $\beta 2)$ is an independent prognostic marker for prostate specific antigen (PSA) failure and postoperative metastasis (POM). In a Kaplan-Meier analysis, the combined expression of both $\mathrm{nER} \beta 2$ and cytoplasmic ER $\beta 5$ identified a group of patients with the shortest POM-free survival. Cox proportional hazard models revealed that nER $\beta 2$ predicted shorter time to POM. In concordance with IHC data, stable, ectopic expression of ER $\beta 2$ or ER $\beta 5$ enhanced PCa cell invasiveness but only PCa cells expressing ER $\beta 5$ exhibited augmented cell migration. This is the first study to uncover a metastasis-promoting role of ER $\beta 2$ and $\mathrm{ER} \beta 5$ in $\mathrm{PCa}$, and show that the two isoforms, singularly and conjointly, have prognostic values for $\mathrm{PCa}$ progression. These findings may aid future clinical management of PCa.
\end{abstract}

Endocrine-Related Cancer (2010) 17 675-689

\section{Introduction}

Prostate cancer (PCa) is the most common cancer and the second leading cause of death among American men (Jemal et al. 2009). Although androgen deprivation therapies (ADTs) remain as the mainstay treatment for advanced PCas, these therapies eventually fail, in part, due to the development of androgen hypersensitivity, ligand-independent androgen receptor (AR) transactivation, and $\mathrm{AR}$ gene mutations and/or amplification in PCas (Scher et al. 2004, Culig \& Bartsch 2006). The recently discovered AR spliced variants in $\mathrm{PCa}$ further raise concerns on the efficacy of these therapies (Dehm et al. 2008, Guo et al. 2009). Thus, limitations revolving around ADTs have prompted exploration of other therapeutic options. Transdermal estrogen patches as a first-line 
therapy in patients with locally advanced or metastatic PCa (Langley et al. 2008) are now in phase II trials. However, despite significant research efforts, the role(s) of estrogen in the pathogenesis of PCa remains poorly understood.

The incidence of PCa rises dramatically in men older than 55. This phenomenon could be due to hormonal changes during aging. Among older men, androgen levels drop significantly, whereas their estrogen levels remain unchanged or increased, making the estrogen to androgen ratio elevated in the aging prostate (Ho et al. 2006). Epidemiological studies indicate a correlation between PCa and circulating estrogen levels, but not circulating testosterone levels, among different ethnic/ racial groups with diverse PCa incidence (Rohrmann et al. 2007). In addition, estrogen is produced locally by aromatase, which converts androgen into estrogen in the prostate (Stone et al. 1986, Matzkin \& Soloway 1992, Ellem et al. 2004, Takase et al. 2006). Estrogens are essential in supporting the normal functioning of the prostate, and yet have long been suspected as a risk factor for PCa. Long-term exposure to elevated levels of estrogen against a normal androgen background induced a high incidence of PCa in rodents (Leav et al. 1988, Prins et al. 2007, Ricke et al. 2008). Also, in utero exposure to higher levels of maternal estrogen in African-American men may be associated with higher PCa risk (Henderson et al. 1988), a thesis supported by animal studies (Prins 1997, Ho et al. 2006, Prins \& Korach 2008).

Estrogen receptors (ER), ER $\alpha$ and ER $\beta$, are the major mediators of estrogen signaling. Upon binding of estradiol-17 $\beta$, ER in the nucleus forms a homo/heterodimer and binds either directly to the classical estrogen-responsive element (ERE) or indirectly to an NFKB-, Ap1-, or Sp1-binding element via tethering with their respective transcription factors, thereby initiating downstream signaling cascades (Heldring et al. 2007). The roles of ERs in the prostate are not fully understood. $\mathrm{ER} \alpha$ is found primarily in stromal cells of the prostate, and appears to regulate the growth and differentiation of prostatic epithelial cells in a paracrine fashion (Ellem \& Risbridger 2009). In the prostatic epithelium, ER $\beta$ is the predominant ER subtype (Kuiper et al. 1996), but its function remains controversial. Hyperplasia and dysplasia have been found in the prostates of adult ER $\beta$ knockout mice (Krege et al. 1998, Weihua et al. 2001), arguing for an antiproliferative role of $\mathrm{ER} \beta$ (Morani et al. 2008). However, other research groups did not observe such phenotypes in their ER $\beta$ knockout mice (Couse et al. 2000, Dupont et al. 2000, Antal et al. 2008). We and others have shown that the expression of ER $\beta$ in human prostate epithelial cells decreases as PCa develops and progresses to a higher grade (Leav et al. 2001, Zhu et al. 2004), but reappears in the lymph node and bone metastases (Lai et al. 2004, Zhu et al. 2004). The dynamic change in ER $\beta$ expression is epigenetically regulated by reversible cytosine methylation of an AP2 site in a $\mathrm{CpG}$ island located in the ER $\beta$ proximal promoter (Zhu et al. 2004, Zhang et al. 2007). These findings suggest that ER $\beta$ may play a protective role during early stages of prostate carcinogenesis, but either promote metastasis or support PCa cell survival at distant sites (Leav et al. 2001). Apropos to the postulate that ER $\beta$ promotes PCa metastasis, a few reports have demonstrated an association between ER $\beta$ immunopositivity in high-grade $\mathrm{PCa}$ and poor relapsefree survival time (Horvath et al. 2001, Nanni et al. 2009). However, further delineation of the role of ER $\beta$ (s) in PCa progression is needed.

The continuing controversy over the function of ER $\beta$ s in prostate carcinogenesis could be due to variable expression levels of different ER $\beta$ isoforms in benign versus malignant tissues during different stages of the process. In humans, in addition to the wild-type ER $\beta$ or $E R \beta 1$, four spliced variants designated as ER $\beta 2-5$ have been identified (Moore et al. 1998). The ER $\beta 2-5$ isoforms share the first four functional domains with ER $\beta 1$, but each has a unique activation function 2 (AF2) domain. Since isoformspecific antibodies were unavailable until very recently, the use of various antibodies directed against different domains of the molecules might have generated immunohistochemistry (IHC) patterns that contradict each other.

No functions for ER $\beta 2-5$ isoforms in the prostate have yet been identified except in one study with 48 cases, suggesting that ER $\beta 2$ may be a poor prognostic marker for PCa (Fujimura et al. 2001). A breast cancer study, however, has implicated nuclear ER $\beta 2$ (nER $\beta 2)$ and nuclear ER $\beta 5$ (nER $\beta 5$ ) to predict better prognosis (Shaaban et al. 2008). To clarify the role of ER $\beta 1$ and its isoforms ER $\beta 2$ and ER $\beta 5$ in PCa, we evaluated the expression patterns of these three ER $\beta s$ in a set of tissue microarrays (TMAs) from a cohort of 144 patients with long follow-up using newly developed in-house isoform-specific antibodies. We found that nuclear expression of ER $\beta 2$ in PCa was an independent prognostic marker for prostate specific antigen (PSA) failure $(\mathrm{PF})$, postoperative metastasis (POM), and time to POM. Furthermore, the coexpression of nER $\beta 2$ and cytoplasmic ER $\beta 5$ (cER $\beta 5$ ) was found associated with the worst prognosis in terms of POM-free survival time. We have further demonstrated that the stable, ectopic expression of ER $\beta 5$ in PCa cells increased cell 
migration and invasiveness without affecting cell growth, while the expression of ER $\beta 2$ augmented only cell invasion. In aggregate, our data suggest that $\mathrm{ER} \beta$ isoforms have variable functions and prognostic values in $\mathrm{PCa}$.

\section{Materials and methods}

\section{Patient population}

With Institutional Review Board (IRB) approval, we included 144 patients with $\mathrm{PCa}$ who underwent radical prostatectomy at the Massachusetts General Hospital (Boston, MA, USA) from September 1993 to March 1995 in this study. All hematoxyolin-eosin (H\&E)stained sections from each case were reviewed, and the Gleason score was reassigned on the basis of the current grading recommendation provided by the International Society of Urological Pathology (Epstein et al. 2005). The tissue blocks containing the index $\mathrm{PCa}$ (tumor focus with the highest Gleason score) were selected for inclusion in the TMA. The relevant clinicopathological data collected included age; preoperative PSA; Gleason score; American Joint Committee on Cancer (AJCC) $\mathrm{T}$ stage; surgical margin; and POM, follow-up of PSA recurrence, and overall survival. PF was any detectable PSA after PSA nadir post-surgery. The value was $0.5 \mathrm{ng} / \mathrm{ml}$ before 1999 and $0.2 \mathrm{ng} / \mathrm{ml}$ since 1999. POM comprised bone and lymph node metastases.

\section{TMA construction}

The TMAs were constructed using a manual tissue array instrument (Beecher Instruments, Silver Spring, MD, USA). Briefly, the H\&E-stained slides were reviewed for accuracy of Gleason scores and for the availability of adequate areas of each component Gleason grade pattern; the index tumor, defined as the largest and/or highest Gleason score, was identified on the slide; and the representative highest Gleason score areas were marked. Three tissue cylinders with a diameter of $0.6 \mathrm{~mm}$ were punched from selected areas of each donor block and brought into a recipient paraffin block. Each block contained normal prostate tissue derived from normal peripheral zone away from the tumor and benign prostatic hyperplasia. The normal tissue serves as an internal control and a reference of staining intensity for adjacent cancer foci. After construction of the TMA blocks, H\&E-stained sections were made for histological evaluation.

\section{Antibodies}

ER $\beta 1$-specific antibody (GC-17, Biogenex, San Ramon, CA, USA) recognizing amino acid residue 502-518 of the AF2 domain was developed in our laboratory, and shown to be highly specific in both western blot and IHC assays (Leav et al. 2001). Polyclonal monospecific antibodies specific for C-terminal peptides within ER $\beta 2$ (482-MKMETLLPEATMEQ-495) and ERß5 (459-LMLLSHVRHARYAP-472) were prepared by immunizing rabbits with the targeted peptide conjugated to BSA according to the affinity-purified package offered by New England Peptide (Gardner, MA, USA). Because we found purified IgGs of ER $\beta 2$ and ER $\beta 5$ to be unstable, we used antisera for all subsequent analyses. The expression of all isoforms in western analyses was confirmed with an N-terminal-specific antibody (H150, Santa Cruz Biotechnology, Santa Cruz, CA, USA).

\section{Western blot analyses}

To evaluate the specificity of our ER $\beta 2$ and ER $\beta 5$ antisera, we expressed various ER $\beta$ isoforms (ER $\beta 1$, ER $\beta 2$, and ER $\beta 5$ ) in HEK293 cells and used these as reagents for testing the specificity of an antiserum. Methods for cell culture maintenance, DNA transfection, and western blot analyses were similar to those previously reported (Leung et al. 2006). The dilution ratio for the primary antibodies used in this study was maintained at $1: 1000$.

\section{IHC analyses}

The detection of ER $\beta 1$, ER $\beta 2$, or ER $\beta 5$ expression on human prostate paraffin-embedded sections was carried out according to our published protocols for ER $\beta 1$ (Leav et al. 2001). The optimal dilution ratio for each primary antiserum was determined empirically, and found to be 1:100 for ER $\beta 1$ and ER $\beta 5$ and 1:500 for ER $\beta 2$. These dilution ratios were used throughout our study. The specificity of ER $\beta 2$ and ER $\beta 5$ antisera was determined by neutralizing each antiserum with a $10 \times$ excess (by weight) of its respective targeted peptide. Peptides derived from ER $\beta 1$ (GCKSSITGSECSPAEDS), ER $\beta 3$ (CSWRLFMLREAS), ER $\beta 4$ (CVRHARWGEKQFIHLK), and ER $\beta 5$ (CSHVRHARYAP) were also applied to the IHC studies to further evaluate the antibody specificity. The antibody-peptide precipitate was removed by centrifugation at $12000 \mathrm{~g}$ for $10 \mathrm{~min}$ after overnight incubation at $4{ }^{\circ} \mathrm{C}$. The supernatant (preabsorbed serum) was used in parallel with the primary antiserum as a negative control to establish specificity of its respective antiserum. 
In TMA studies, sections were stained according to the same IHC protocol. IHC results were scored, evaluated, and graded independently in a blinded fashion by two investigators (C-L W and $\mathrm{S} W$ ), including one experienced urological pathologist (C-L W). Nuclear and cytoplasmic signals of each ER $\beta$ isoform were examined separately. Signal intensity and percentage of signal coverage of each region were scored according to the Allred scoring system (Allred et al. 1993). The intensity signal was graded from 0 to 3 (0, none; 1, weak; 2, intermediate; 3 , strong), and the percentage of positive tumor cells was scored from 1 to $5(1,<1 \% ; 2,1-10 \%, 3,10-30 \% ; 4,30-60 \%$; $5,>60 \%)$. For example, if the same specimen was not stained by either of the antibodies, it will be scored as $0+1$ (Allred score (Ascore) $=1$, i.e. negative) .

\section{Subcellular localization studies}

PC3 cells (ATCC, Manassas, VA, USA) were maintained under standard conditions and cultured on coverslips. A full-length sequence of ER $\beta$ isoforms 1, 2 , and 5 was subcloned into pEF-yellow fluorescent protein (YFP)-C1 (Clontech) and expressed as a fusion protein with an $\mathrm{N}$-terminal YFP tag in PC3 cancer cells following the Lipofectamine 2000 (Invitrogen) transfection protocol. At $48 \mathrm{~h}$ after transfection, cells were incubated with $250 \mathrm{nM}$ Mito-tracker Red CM-H2XRos (Invitrogen) for $45 \mathrm{~min}$ and fixed with $4 \%$ formaldehyde for $15 \mathrm{~min}$. Cells were then permeabilized with $0.2 \%$ Triton $\mathrm{X}-100$ before their nuclei were counterstained with $300 \mathrm{nM} \mathrm{4}$,6-diamidino-2-phenylindole (DAPI) (Invitrogen) and preserved in Prolong Antifade Gold reagent (Invitrogen). Fluorescent signals were captured and evaluated with an Axiovert 200M fluorescent microscope equipped with an AxioCam MRm camera and Axiovision 4.7 software (Carl Zeiss, Thornwood, NY, USA). Optical sections were generated using ApoTome (Carl Zeiss).

\section{Construction of PC3 cells stably expressing ER $\beta$ isoforms}

Full-length sequences of $E R \beta 1, E R \beta 2$, and $E R \beta 5$ were subcloned into a pLenti6 lentiviral vector recombined with an ubiquitin promoter by Multisite Gateway recombination reactions (Invitrogen) and transfected into 293FT cells for production of lentivirus according to the manufacturer's protocol. Lentivirus carrying the $L a c Z$ gene was used as a control. The use of the ubiquitin promoter, which is a constitutive but relatively weak promoter, minimized artifacts introduced by other virus-based promoters. The titer of each lentivirus was measured, and the multiplicity of infection of PC3 cells was 0.7. Lentivirus-infected PC 3 cells were cultured in medium supplemented with blasticidin at $8 \mu \mathrm{g} / \mathrm{ml}$ and selected for 3 weeks. PC3 cells stably expressing LacZ, ER $\beta 1$, ER $\beta 2$, and ER $\beta 5$ were designated as PC3-LacZ, PC3-ER $\beta 1$, PC3-ER $\beta 2$, and PC3-ER $\beta 5$ respectively. Expression of the transgenes was confirmed by real-time PCR assays.

\section{Cell migration and invasion assays}

Cellular mobility of PC3-LacZ, PC3-ER $\beta 1$, PC3-ER $\beta 2$, and PC3-ER $\beta 5$ cells was evaluated with a wound-healing assay (Rodriguez et al. 2005), and their invasiveness through the extracellular matrix was determined by the BD BioCoat Matrigel Invasion Chamber method (BD Biosciences, San Jose, CA, USA) following the manufacturer's protocol.

\section{Statistical analysis}

Descriptive statistics were calculated for demographic and clinical measures. Preliminary associations between Ascores measuring the expression level of cytoplasmic and $n E R \beta 1,2$, and 5 were analyzed using Mantel-Haenszel $\chi^{2}$ test statistics to evaluate associations with PF and POM. A significant relationship with at least one outcome was found for one isoform of each type $(P<0.05)$. These Ascores were included in logistic regression analyses, adjusted for Gleason score and age. Ascores were dichotomized at cutpoints where slopes of Ascores changed, determined by statistical evaluations of curves fitted to the data, and visual assessment. Two cutpoints were chosen for each outcome and each Ascore. The best model was chosen by evaluating goodness-of-fit statistics. Cox proportional hazard models were used to analyze time to PF and time to POM. Kaplan-Meier plots of PF and POM survival were analyzed, stratified by dichotomized cytoplasmic and nuclear levels. An $\alpha$-level of 0.05 was used to determine significance, unless otherwise stated. Analyses were performed with SAS for Windows, Version 9.1.2 (SAS Institute, Cary, NC, USA) and GraphPadPrism4 (La Jolla, CA, USA).

\section{Results}

\section{Evaluation of ERß2 and ERß5 antisera for isoform specificity}

A specific antibody targeting each isoform is necessary for studying the expression of ER $\beta$ isoforms. An ER $\beta 1$-specific antibody (GC17) that we had raised previously has been widely used in PCa research (Leav et al. 2001, Adams et al. 2002, Pais et al. 2003, 

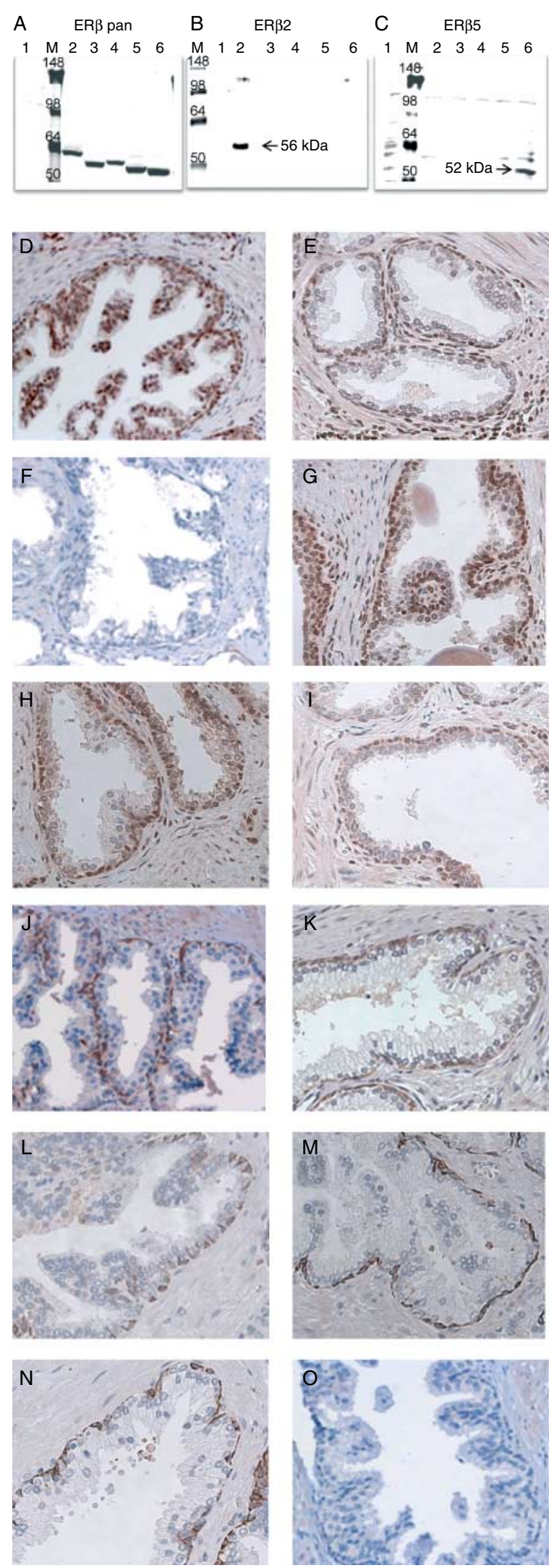

Zhu et al. 2004). We recently also developed polyclonal monospecific antisera to ER $\beta 2$ and ER $\beta 5$ based on isoform-specific C-terminal sequences. We first overexpressed full-length ER $\beta 1,2,3,4$, or 5 expression plasmids (Leung et al. 2006) in HEK293 cells and used the cell lysates to test the specificity of ER $\beta 2$ and ER $\beta 5$ antiserum by western blot analysis. We used a pan-ER $\beta$ antibody to confirm the expression of each ER $\beta$ isoform protein in HEK293 cells (Fig. 1A). We then reblotted the same lysates with ERß2-specific (Fig. 1B) or ERß5-specific (Fig. 1C) antiserum. ER $\beta 2$-specific antiserum recognized a single 56-kDa band in lane 3 , which was loaded with a lysate from HEK293 cells expressing the ER $\beta 2$ transgene. No cross-reactivity with other isoforms (lanes 2, 4, 5, and 6) was detected in this ERß2 western blot. Similarly, the ER $\beta 5$ antiserum strongly recognized a 53-kDa band in lane 6 that was loaded with a lysate from HEK293 cells harboring the ER $\beta 5$ transgene.

We then investigated whether we could use the new antisera for IHC. To validate the specificity of an antiserum, we immunostained serial prostate archival sections with or without ER $\beta$ isoform-specific peptides. At low magnification $(\times 100)$, the ER 32 antiserum primarily stained the cytoplasm of the basal and luminal epithelial cells of benign glands (Fig. 1D) and also stained the nuclei of some stromal cells. The immunopositive signals were not blocked by other $\mathrm{ER} \beta$ isoform-specific peptides (Fig. 1E, G, H, and I) but totally abolished by the ER $\beta 2$ peptide (Fig. 1F). These results showed that the specificity of ER $\beta 2$ antiserum for ER $\beta 2$ was excellent. Similarly, ER $\beta 5$ antibody strongly stained the cytoplasm of basal epithelial cells but not the luminal epithelial cells $(\times 100)$ and weakly stained some stromal cells

Figure 1 Specificity of ER $\beta$ isoform-specific antibodies. Western blot analyses: HEK293 cells expressing ER $\beta 1-5$ lysate were tested against ER $\beta$ pan antibody $((A)$ Santa Cruz H150), ER $\beta 2$-specific antibody (B), and ER $\beta 5$-specific antibody (C). Lane 1 was loaded with control cell lysate (HEK293 cells only), whereas lanes 2-6 were loaded with HEK293 cell lysate expressing ER $\beta 1-5$ respectively. $M$ stands for protein marker (Invitrogen SeeBlue Plus2 protein ladder). The expected protein band of the ER $\beta$ isoforms 2 and 5 was labeled by an arrow in the middle and right panel respectively.

Immunohistochemical (IHC) analyses: IHC analyses of benign prostatic tissue were carried out using ER $\beta 2-(D-I)$ and $\beta 5$-specific antisera (J-O). ER $\beta 1-$-, ER $\beta 2-$, ER $\beta 3-$, ER $\beta 4-$, and ER $\beta 5$-specific peptides were applied to the IHC analyses. Figures showing IHC analyses with or without ER $\beta$ isoformspecific peptide are arranged as follow: $\mathrm{D}$ and $\mathrm{J}$ (no peptide); $\mathrm{E}$ and $\mathrm{K}$ (+ERß1 peptide); $\mathrm{F}$ and $\mathrm{L}$ ( + ER $\beta 2$ peptide); $\mathrm{G}$ and $\mathrm{M}$ (+ERß3 peptide); $\mathrm{H}$ and $\mathrm{N}$ ( + ER $\beta 4$ peptide); I and $\mathrm{O}$ (+ERß5 peptide). 
(Fig. 1J). Such immunopositive signals of ER $\beta 5$ were totally eliminated by its blocking peptide (Fig. 1O) but not by other isoform-specific peptides (Fig. 1K, L, M, and $\mathrm{N}$ ), verifying the specificity of ER $\beta 5$ antiserum for IHC analyses.

\section{Immunocytochemistry analyses of ER $\beta$ isoforms in PCa specimens}

Although we showed the antisera to be specific to their respective antigen, we also found that they may crossreact with other ER $\beta$ isoforms. We therefore further examined our ER $\beta$-stained sections at high magnification $(\times 630)$ to determine whether the staining pattern was unique for each antibody/antiserum. Immunostained benign glands (Fig. 2A-F) and cancer foci, consisting of Gleason grade 3 cancer glands (Fig. 2G-M), were compared in parallel. In benign prostate glands, ER $\beta 1$ was localized principally in the nuclei of basal epithelial cells (Fig. 2A and D) as previously reported for GC17 staining (Leav et al. 2001). ER $\beta 1$ was also localized in the nuclei of a few luminal epithelial cells but was found quite frequently in the perinuclear zone in luminal epithelial cells. The nuclei of some stromal cells were also strongly stained by the ER $\beta 1$ antibody (GC17). In contrast, the ER $\beta 2$ was localized predominantly to the cytoplasm of both basal and luminal epithelial cells, with clear localization in the supranuclear zone of the luminal cells (Fig. 2B and E); nuclear localization was uncommon. ER $\beta 5$, however, was localized almost exclusively in basal epithelial cells in benign prostate glands
(Fig. 2C and F); intracellular localization was primarily cytoplasmic. In PCa, such as in Gleason score $6(3+3)$ cancer foci (Fig. 2K), some foci of ERß1 positivity were lost in both nuclear and cytoplasmic compartments, but some remained (Fig. 2J). ER $\beta 2$ (Fig. 2H and L) and ER $\beta 5$ (Fig. 2I and M), however, displayed a diffused pattern of cytoplasmic staining, with occasional nuclear positivity. In summary, the three antibodies/antirsera produced distinct staining patterns in both benign glands and cancerous prostatic foci, thereby providing support for the suggestion that each of them is highly specific and probably recognizes only one ER $\beta$ isoform in IHC studies.

\section{Subcellular localization of ER $\beta$ isoforms in PCa cells}

To elucidate the subcellular localization of ER $\beta$ isoforms in PCa cells, we ectopically expressed ER $\beta 1$, ER $\beta 2$, or ER $\beta 5$ in PC 3 cells in the form of an YFP fusion protein, with YFP serving as a control (Fig. 3A-D). YFP-ER $\beta 1$ was found principally in the nucleus, with very weak signals in the cytoplasm (Fig. 3E). The cytoplasmic signal did not overlap the Mito-tracker red signal (Fig. 3G), suggesting that ER $\beta 1$ does not reside in mitochondria in PC 3 cells. Similarly, the YFP signal of ERß2 (Fig. 3I) and ER $\beta 5$ (Fig. 3M) was found in both the nuclei and cytoplasm of the PC3 cells, and no overlapping signal with the Mito-tracker red signals was detected in both cases (Fig. 3K and O). Of interest was the stronger cytoplasmic signal of YFP-ER $\beta 5$ among the ER $\beta$ isoforms.

\section{Normal}
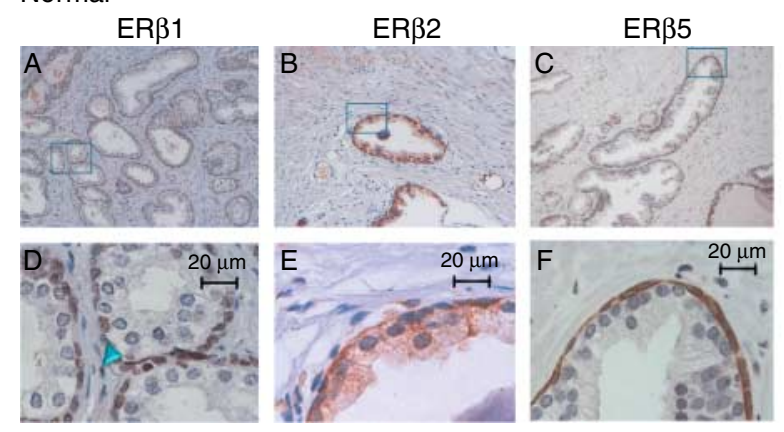

Grade score 6
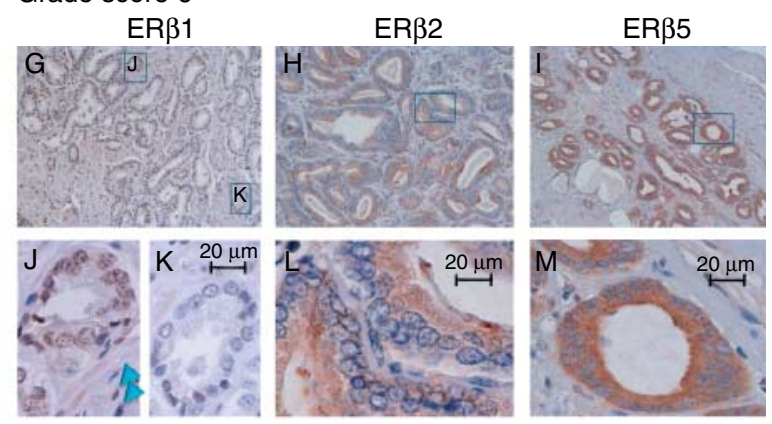

Figure 2 Immunohistochemical analyses of $E R \beta$ isoforms in benign prostate glands (A-F) and prostate adenocarcinoma in PCa specimen (G-M). PCa specimens from cancers with Gleason score $6(G-M)$ and its adjacent normal region (A-F) were immunostained with ER $\beta 1$-, ER $\beta 2$ - and ER $\beta 5$-specific antibodies/antisera. See Materials and methods for the experimental conditions. Figures D-F and J-M are the magnified view $(\times 630)$ of a region (marked by a rectangle) in Figure $A-C$ and $G-I(\times 100)$ respectively. In ER $\beta 1$ immunostaining, positive signals were found mostly in the nuclei of basal epithelial cells in benign foci $(A$ and $D)$ and in the nuclei of PCa cells ( $G$ and $J$ ) despite sparse nuclear staining in stromal cells (indicated by light blue arrow heads in figures $D$ and $\mathrm{J}$ ). ER $\beta 1$ staining was lost in some PCa foci $(\mathrm{K})$. ER $\beta 2$ staining is highly cytoplasmic in both benign (basal and luminal epithelial cells, $B$ and $E$ ) and PCa foci ( $\mathrm{H}$ and $\mathrm{L})$. Immunopositive signals of ER $\beta 5$ were observed in the cytoplasmic region of the epithelial cells in adjacent normal foci ( $\mathrm{C}$ and $\mathrm{F})$ as well as in PCa cells in Gleason score 6 cancer (I and $\mathrm{M})$. 
Fluorescent
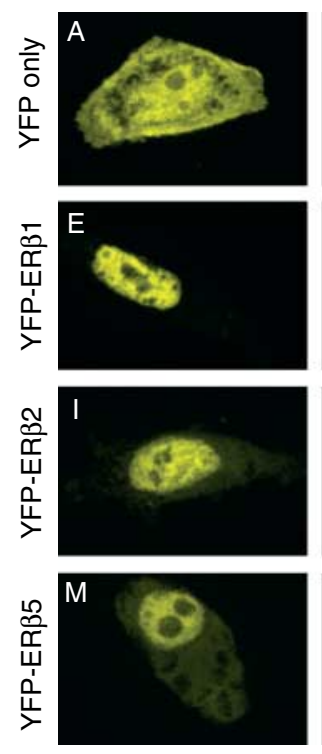

Nucleus
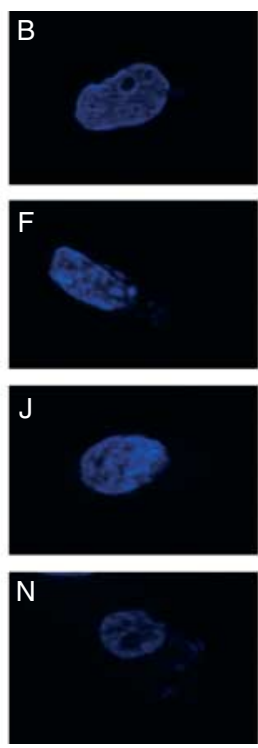

Mitochondria
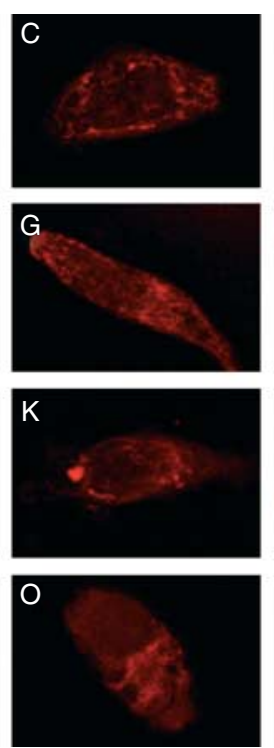

Merged
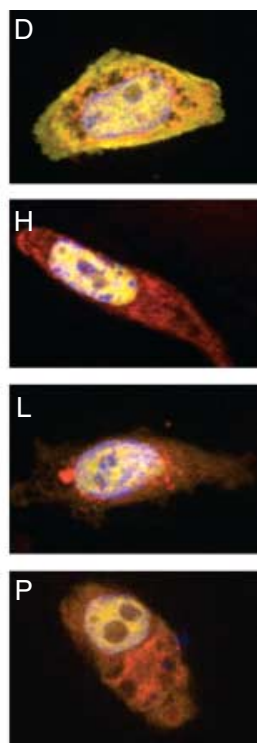

Figure 3 Subcellular localization of ER $\beta$ isoforms in PC3 cells. Vectors carrying $E R \beta 1(\mathrm{E}-\mathrm{H}), E R \beta 2(\mathrm{I}-\mathrm{L})$, and $E R \beta 5(\mathrm{M}-\mathrm{P})$ were transiently transfected into PC3 cells, and expressed in the form of fusion protein with an N-terminal YFP tag. Cells transfected with YFP only serve as a control (A-D). Cells were counterstained with nucleus-specific (DAPI, B, F, J, and N) and mitochondria-specific fluorescent dyes (Mito-tracker red, C, G, K, and O). Subcellular localization of each isoform was determined by fluorescence microscopy. Extended focus was applied to average and combine three optical sections of each signal. Merged images of YFP, DAPI, and Mito-tracker red signals are shown in D, H, I, and P.

\section{Characteristics of the patients whose prostates were used to construct the TMA}

The majority of the patients $(n=133)$ were CaucasianAmericans (92.4\%; Table 1). Only 11 were nonCaucasian: African-American (3.5\%), Hispanic (2.8\%), or Asian (1.4\%). Ages ranged from 46 to 77 years $($ mean $=62)$. Approximately $44 \%$ of the patients had low-grade cancer (Gleason score <7), $40 \%$ had intermediate-grade PCa (Gleason score $=7$ ), and $16 \%$ had higher-grade cancer (Gleason score $>7$ ). The postoperative PSA levels of patients were measured for an average of 6.2 years. PF was detected in $37.5 \%$ of the patients $(n=54)$. POM was found in $8.3 \%$ of the patients $(n=12)$. The average time to PF and POM was 6.2 and 8.6 years respectively.

\section{TMA analyses}

To elucidate the clinical relevance of the expression of ER $\beta 1, E R \beta 2$, and ER $\beta 5$ in PCa, we used our newly validated antisera and ER $\beta 1$-specific antibody (GC17) in an IHC analysis of a set of TMAs comprising 144 specimens with a well-documented clinical history. Figure 4 shows typical results of IHC staining with ER $\beta 1,2$, or 5 antibody/antisera. Typical TMA sections showing low to moderate staining of ER $\beta$ isoforms are shown in Fig. 4A, D, and G. In a few rare instances, both nuclear and cytoplasmic staining of ER $\beta$ isoforms was observed in some of the TMA sections (Fig. 4B, E, and $\mathrm{H})$. With higher magnification $(\times 630)$, nuclei in PCa cells were differentially stained by the isoforms antibody/antisera (Fig. 4C, F, and I). We noted different staining patterns in some specimens of similar cancer grade even with the same antibody/antiserum and IHC conditions. Variations were greater in the specimens positive for ER $\beta 1$ and ER $\beta 5$. The pattern for ER $\beta 2$ was less variable.

\section{Distinct subcellular localization patterns of ER $\beta$ isoforms in PCa specimens}

$E R \beta 1,2$, and 5 showed distinctly different expression patterns in this set of PCa TMAs. ER $\beta 2$ was found to be the dominant ER $\beta$ isoform in PCa (Fig. 5). Over $80 \%$ of the samples $(n=127)$ showed a positive ER $\beta 2$ signal. Most of the ER $\beta 2(n=108)$ was localized in the cytoplasm of the PCa cells, but $\sim 10 \%$ resided in the nucleus. ER $\beta 1$ was the second most common isoform in this set of TMAs. Since $84 \%$ of the patients $(n=121)$ had intermediate-grade PCa (Gleason 5-7) at prostatectomy, in agreement with previous studies, most of their prostate specimens still retained ER $\beta 1$ staining (Fig. 2; Leav et al. 2001). In contrast to the 
Table 1 Characteristics of 144 patients

\begin{tabular}{lc}
\hline Variables & $\boldsymbol{n}$ (\% total patients) \\
\hline Age (years) & \\
$46-50$ & $4(2.8)$ \\
$50-59$ & $49(34.0)$ \\
$60-69$ & $81(56.3)$ \\
$70-77$ & $10(6.9)$ \\
Race & \\
Caucasian-American & $133(92.4)$ \\
African-American & $5(3.5)$ \\
Hispanics & $4(2.8)$ \\
Asian & $2(1.4)$ \\
Pathology stage & $115(79.9)$ \\
T2 & $29(20.1)$ \\
T3 & \\
Gleason score & $63(43.8)$ \\
$<7$ & $58(40.2)$ \\
$=7$ & $23(16.0)$ \\
$>7$ & \\
Surgical margin & $58(40.3)$ \\
Positive & $86(59.7)$ \\
Negative & \\
PSA failure & $54(37.5)$ \\
Yes & $90(62.5)$ \\
No & $12(8.3)$ \\
Metastasis & $132(91.7)$ \\
Detected & \\
Not detected & \\
\hline
\end{tabular}

exclusive nuclear localization of ER $\beta 1$ in basal cells of benign glands, ER $\beta 1$ was found more often in both the nuclear and cytoplasmic compartments or in only the cytoplasmic compartment of PCa cells. ER $\beta 5$ is the least common isoform; only $36 \%$ of patients $(n=52)$ showed ER $\beta 5$ positivity, which was predominantly expressed in the cytoplasm of the cancer cells $(>90 \%$ of the cases, $n=49$ ).

Since we had previously shown that the various $\mathrm{ER} \beta$ isoforms formed heterodimers with ER $\beta 1$ in cell culture under different conditions of ligand stimulation (Leung et al. 2006), we calculated Spearman correlation analyses to determine the possibility of finding two of the three ER $\beta s$ in the same cellular compartment in the $\mathrm{PCa}$ specimens (Table 2). Despite low-to-moderate correlations, a significant difference from zero was found for the correlation between ER $\beta 1$ and ER $\beta 2$ in the nucleus $(r=0.45)$ and the cytoplasm $(r=0.39 ; P<0.01)$, suggesting that ER $\beta 1$ and ER $\beta 2$ may be coexpressed in the nuclei or cytoplasm of PCa cells. ER $\beta 5$, which is predominantly cytoplasmic, therefore showed a better correlation only with cER $\beta 1 \quad(r=0.37)$ and cER $\beta 2 \quad(r=0.26 ; P<0.01)$, implying that some specimens may coexpress ER $\beta 5$ with at least one other ER $\beta$.

\section{Statistical results of TMA studies}

nER $\beta 2$ and cER $\beta 5$ Ascores were significantly related to $\mathrm{PF}$ and/or POM. Ascores were dichotomized as negative $(\leq 3)$ and positive $(>3)$ based on statistical assessment and results of a previously published study (Shaaban et al. 2008). Descriptive statistics evaluating differences between dichotomized Ascores and clinicopathological features of $\mathrm{PCa}$ showed that age, preoperative PSA, and Gleason score were significantly different $(P<0.10)$ for at least one isoform (nER $\beta 2$ and cER $\beta 5$; Table 3). Positive expression of nER $\beta 2$ was significantly associated with PF (adjusted odds ratio $(\operatorname{adjOR})=3.8, \quad P=0.04)$ and $P O M$ $(\operatorname{adjOR}=3.1, P=0.02)$, while $\mathrm{cER} \beta 5$ positivity did not show a significant association with either $\mathrm{PF}$ $(\operatorname{adjOR}=0.8, \quad P=0.58)$ or $\mathrm{POM} \quad(\operatorname{adjOR}=3.1$, $P=0.09$; Table 3 ). Significantly poorer survival (time to POM), independent of Gleason score, age, and preoperative PSA, was associated with nER $\beta 2$ positivity (adjusted hazard ratio adjHR $=4.6, P=0.02$ ). These results suggest that $\mathrm{nER} \beta 2$ is an independent prognostic marker for predicting time to POM. Time to $\mathrm{PF}$ was not significantly associated with positivity of nER $\beta 2$ or cER $\beta 5(P>0.05)$. Kaplan-Meier plots and the log-rank test statistics showed that time to PF and time to POM were significantly shorter for patients with nER $\beta 2$ positivity $(P<0.01$; Fig. $6 \mathrm{~A}$ and $\mathrm{B})$. cER $\beta 5$ positivity, on the other hand, was significantly

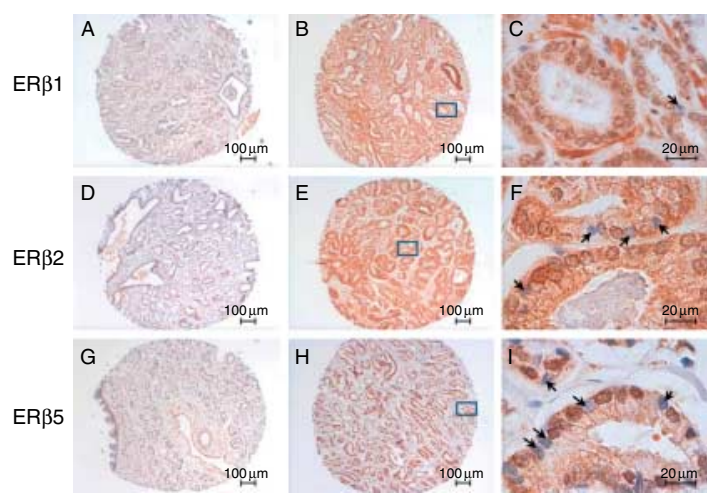

Figure 4 Typical IHC results of ER $\beta$ immunostaining on TMAs. TMAs with 144 specimens were immunostained with ER $\beta 1$ $(\mathrm{A}-\mathrm{C}), \mathrm{ER} \beta 2$ (D-E), and ER $\beta 5$ (G-I) antibodies/antisera. The Allred scoring system (Allred score= signal score+intensity score) was used to grade the immunostaining signals. Typical low Allred-scored sections (Allred $=0+1$ for nuclear positivity; Allred $=1+2$ to $1+3$ for cytoplasmic positivity) are shown in A, D, and G. Higher Allred-scored sections (Allred $=3+5$ for both nuclear and cytoplasmic positivity) with strong nuclear and cytoplasmic staining are shown in B, E, and H. C, F, and I represent a magnified view $(\times 630)$ of a region (marked by a rectangle) in $\mathrm{B}, \mathrm{E}$, and $\mathrm{H}$ respectively. Negative nuclear staining in $\mathrm{C}, \mathrm{F}$, and $\mathrm{I}$ is marked by solid arrows. 


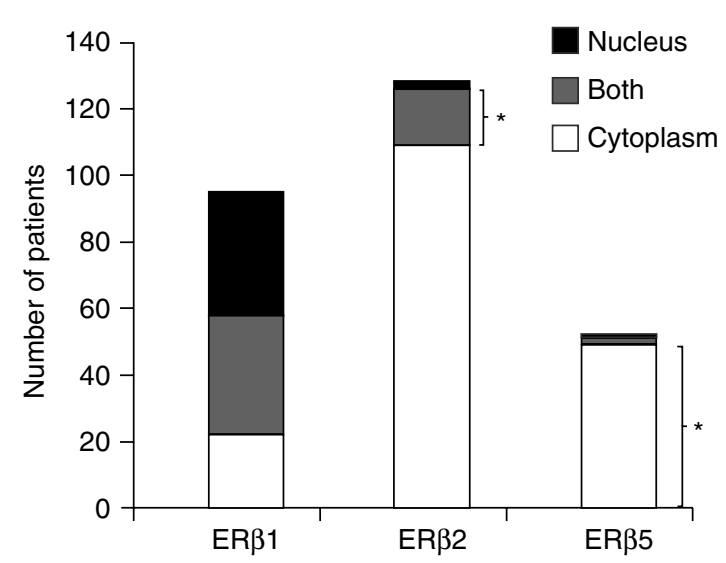

Figure 5 Distribution of ER $\beta$ isoforms in this prostate cancer TMA. The immunopositivity signal of each isoform was graded according to the Allred scoring system. Only an Allred score greater than cutpoint (i.e. Allred >3) was considered positive. The number of patients showing positive immunostaining signals in different cellular compartments was determined and analyzed. The correlations between two ER $\beta$ isoform expression were determined based on Spearman correlation test. $P<0.05$ was considered to be statistically significant. An asterisk represents a specific group of patients with a higher possibility of showing the worst clinical outcome.

associated only with a reduced survival time to POM $(P=0.03$; Fig. 6C) but not time to PF $(P>0.05$, data not shown). In a combined analysis, patients whose prostate specimen was positive for both nER $\beta 2$ and cER $\beta 5$ had the shortest POM-free survival $(P<0.01$, degrees of freedom $=3$ ), i.e. worst clinical outcome (Fig. 6D). Comparisons among pairs of groups revealed that the group with a double positive for nER $\beta 2$ and cER $\beta 5$ was significantly different from the group with a double negative $(P<0.01)$ and with the group with only nER $\beta 2$ positive $(P=0.04)$.

\section{Migration and invasion of PCa cells expressing $E R \beta$ isoforms}

On the basis of the results from the TMA study suggesting that both ER $\beta 2$ and ER $\beta 5$ could be the markers for predicting time to POM, we further investigated the role of these two isoforms in $\mathrm{PCa}$ metastasis. We stably infected $L a c Z, E R \beta 1, E R \beta 2$, and $E R \beta 5$ in PC3 cells with lentivirus, and measured cell mobility and invasion ability of the cells expressing different isoforms with wound-healing and invasion assays respectively. Stable ectopic expression of each ER $\beta$ isoform in PC3 cells was confirmed with established real-time PCR assays (Leung et al. 2006). A greater than 200-fold increase in ER $\beta$ transcript was detected in each stable-transfected cell line. In woundhealing assays, PC3-ER $\beta 5$ cells migrated significantly faster than the others after $24 \mathrm{~h}$ of wound introduction (Fig. 7A). PC3-ER 32 cells migrated as fast as the PC3-LacZ control cells, but PC3-ER $\beta 1$ cells migrated significantly more slowly than control cells. In invasion assays, the efficiency of invasion across the matrix gel membrane of PC3-ER $\beta 2$ and PC3-ER $\beta 5$ cells was 64 and $42 \%$ respectively greater than that of PC3-LacZ cells within $24 \mathrm{~h}$ (Fig. 7B). Interestingly, ectopic expression of ER $\beta 1$ in PC 3 cells significantly reduced PCa cell invasiveness by $34 \%$ as compared with PC3-LacZ.

\section{Discussion}

This is the first study comparing the protein expression of ER $\beta 1$ with that of its isoforms ER $\beta 2$ and ER $\beta 5$ in specimens from a cohort of patients with PCa $(n=144)$ with long clinical follow-up. The immunohistochemical expression of the three ER $\beta$ s was analyzed in a set of TMAs derived from the cohort using an ER $\beta 1$ specific antibody and two newly characterized antisera for ER $\beta 2$ and ER $\beta 5$. nER $\beta 2$ was found to be an independent predictor for $\mathrm{PF}$ (adjOR $=3.8, P=0.04$ ), POM $(\operatorname{adjOR}=3.1, P=0.02$ ), and POM-free survival $(\operatorname{adjHR}=4.6, P=0.02)$, whereas cER $\beta 5$ was a predictor for POM-free survival in Kaplan-Meier analysis. More importantly, patients positive for both $\mathrm{ER} \beta$ isoforms (nER $\beta 2+$ and $\mathrm{cER} \beta 5+$ ) were found to have the shortest POM-free survival $(P<0.01)$. To provide mechanistic insights into the clinical relevance and prognostic significance of both isoforms, we ectopically expressed ER $\beta$ isoforms in PC3 cells and

Table 2 Spearman correlation $S(r)$ between expression of estrogen receptor $\beta 1$ (ER $\beta 1)$, ER $\beta 2$, and ER $\beta 5$ isoform

\begin{tabular}{|c|c|c|c|c|c|}
\hline & \multirow[b]{2}{*}{$n^{a}$} & \multicolumn{2}{|c|}{ Nucleus } & \multicolumn{2}{|c|}{ Cytoplasm } \\
\hline & & $r$ & $P$ value & $r$ & $P$ value \\
\hline ER $\beta 1$ versus $E R \beta 2$ & 134 & 0.45 & $<0.01$ & 0.39 & $<0.01$ \\
\hline ER $\beta 1$ versus ER $\beta 5$ & 134 & 0.10 & 0.23 & 0.38 & $<0.01$ \\
\hline ER $\beta 2$ versus ER $\beta 5$ & 134 & 0.06 & 0.48 & 0.24 & $<0.01$ \\
\hline
\end{tabular}

$P$ values testing $r=0$.

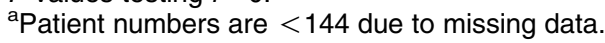


Table 3 Descriptive statistics and results of regression analyses

\begin{tabular}{|c|c|c|c|c|c|c|}
\hline & \multicolumn{3}{|c|}{ Nuclear $\operatorname{ER\beta 2}\left(n=136^{\mathrm{a}}\right)$} & \multicolumn{3}{|c|}{ Cytoplasmic ER $\beta 55\left(n=137^{\mathrm{a}}\right)$} \\
\hline & Positive $^{\text {b }}(\%)$ & Negative $^{\mathrm{b}}(\%)$ & $P$ value & Positive $^{b}(\%)$ & Negative $^{\mathrm{b}}(\%)$ & $P$ value \\
\hline \multicolumn{7}{|c|}{ Clinicopathological features of $\mathrm{PCa}$} \\
\hline Number of patients $(n)$ & 21 & 115 & & 56 & 81 & \\
\hline \multicolumn{7}{|l|}{ Age (years) } \\
\hline Mean \pm S.D. & $59.5 \pm 5.9$ & $62.3 \pm 6.1$ & 0.06 & $62.3 \pm 6.1$ & $61.7 \pm 6.3$ & 0.58 \\
\hline \multicolumn{7}{|l|}{ Preoperative PSA (ng/ml) } \\
\hline Median (min, max) & $5.0(3.0,20.1)$ & $6.8(0.05,32.3)$ & 0.03 & $6.6(0.3,32.3)$ & $\begin{array}{c}6.2(0.05 \\
23.2)\end{array}$ & 0.71 \\
\hline \multicolumn{7}{|l|}{ Gleason score } \\
\hline$<7$ & $4(19.1)$ & $53(46.1)$ & & $22(39.3)$ & $36(44.4)$ & \\
\hline$=7$ & $13(61.9)$ & $44(38.3)$ & 0.06 & $22(39.3)$ & $35(43.2)$ & 0.36 \\
\hline$>7$ & $4(19.1)$ & $18(15.7)$ & $(d f=2)$ & $12(21.4)$ & $10(12.4)$ & $(\mathrm{df}=2)$ \\
\hline \multicolumn{7}{|l|}{ Pathology stage ${ }^{c}$} \\
\hline $\mathrm{T} 2$ & $19(90.5)$ & $89(77.4)$ & & $43(76.8)$ & $66(81.5)$ & \\
\hline T3 & $2(9.5)$ & $26(22.6)$ & 0.14 & $13(23.2)$ & $15(18.5)$ & 0.50 \\
\hline \multicolumn{7}{|l|}{ Surgical margins } \\
\hline Positive & 7 (33.3) & $50(43.5)$ & & $25(44.6)$ & $32(39.5)$ & \\
\hline Negative & $14(66.7)$ & $65(56.5)$ & 0.47 & $31(55.4)$ & $49(60.5)$ & 0.60 \\
\hline \multicolumn{7}{|l|}{ PSA failure } \\
\hline Yes & $14(66.7)$ & 39 (33.9) & & $22(39.3)$ & 31 (38.3) & \\
\hline No & 7 (33.3) & $76(66.1)$ & $<0.01$ & $34(60.7)$ & $50(61.7)$ & 0.90 \\
\hline \multicolumn{7}{|l|}{ Post-operative metastasis } \\
\hline Yes & $5(23.8)$ & $7(6.1)$ & & $8(14.3)$ & $4(4.9)$ & \\
\hline No & $16(76.2)$ & $108(93.9)$ & $<0.01$ & $48(85.7)$ & 77 (95.1) & 0.06 \\
\hline Outcome & adjOR & $\operatorname{adjHR}$ & $P$ value & adjOR & $\operatorname{adjHR}$ & $P$ value \\
\hline \multicolumn{7}{|c|}{ Adjusted odds ratio $\left(\operatorname{adjOR}^{d}\right)$ and hazard ratio $\left(\operatorname{adjH} R^{d}\right)$} \\
\hline PSA failure & 3.8 & & 0.04 & 0.8 & & 0.58 \\
\hline Time to PSA failure & & 1.8 & 0.10 & & 0.8 & 0.47 \\
\hline Post-operative metastasis & 3.1 & & 0.02 & 3.1 & & 0.09 \\
\hline $\begin{array}{l}\text { Time to post-operative } \\
\text { metastasis }\end{array}$ & & 4.6 & 0.02 & & 3.1 & 0.07 \\
\hline
\end{tabular}

found that stable expression of these isoforms in this cell line increased the efficiency of cell migration (for PC3-ER $\beta 5$ cells) and cell invasiveness (for both PC3-ER $\beta 2$ and PC3-ER $\beta 5$ cells) but did not alter cell proliferation (unpublished data). Taken together, these findings established that ER $\beta 2$ and ER $\beta 5$ are strongly associated with PCa metastasis.

Estrogen has been shown to be involved in normal and malignant functions of the prostate (Ho et al. 2006). Four decades ago, the oral estrogen diethylstilbestrol was the treatment of choice for $\mathrm{PCa}$ (Huggins \& Hodges 2002). It was ultimately abandoned because of its serious cardiovascular and thromboembolic toxicity (Hanash et al. 1970, Eisen et al. 1975) and the emergence of gonadotropin agonists/antagonists (Schally et al. 1983). However, other forms of estrogen, including various ER selective modulators, recently have emerged as effective and economical therapies, largely because of clinical data showing minimal hepatic toxicity of these agents if they are administrated parentally via an intramuscular or transdermal route (Ockrim et al. 2006). These therapies also have significant efficacy in protecting against osteoporotic fracture, hot flashes, asthenia, and cognitive dysfunction in patients with $\mathrm{PCa}$ (Ockrim et al. 2006). With this renewed interest in using estrogens as single or combination therapy for $\mathrm{PCa}$, the need to understand how ERs affect PCa is pressing. 
A

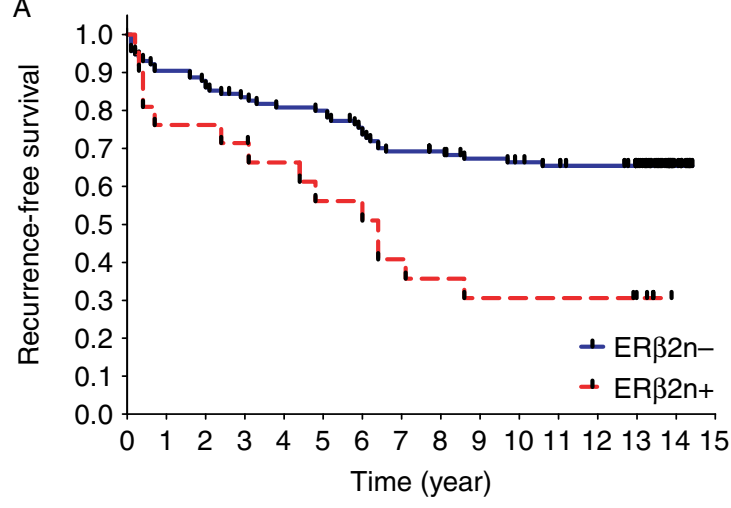

B

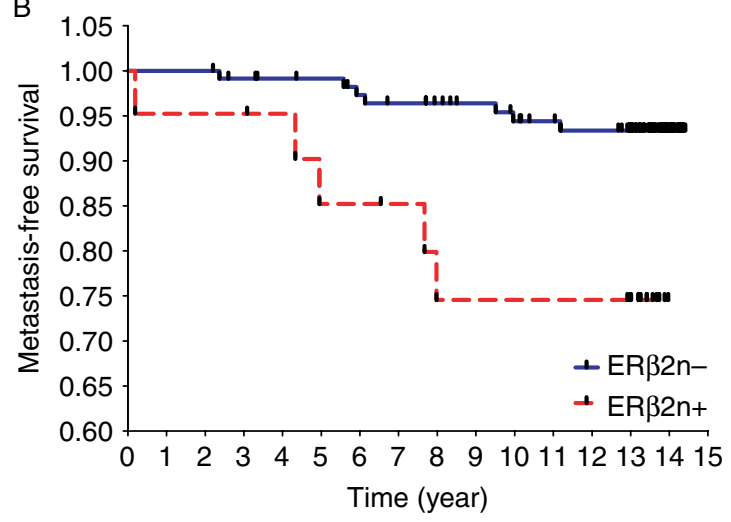

C
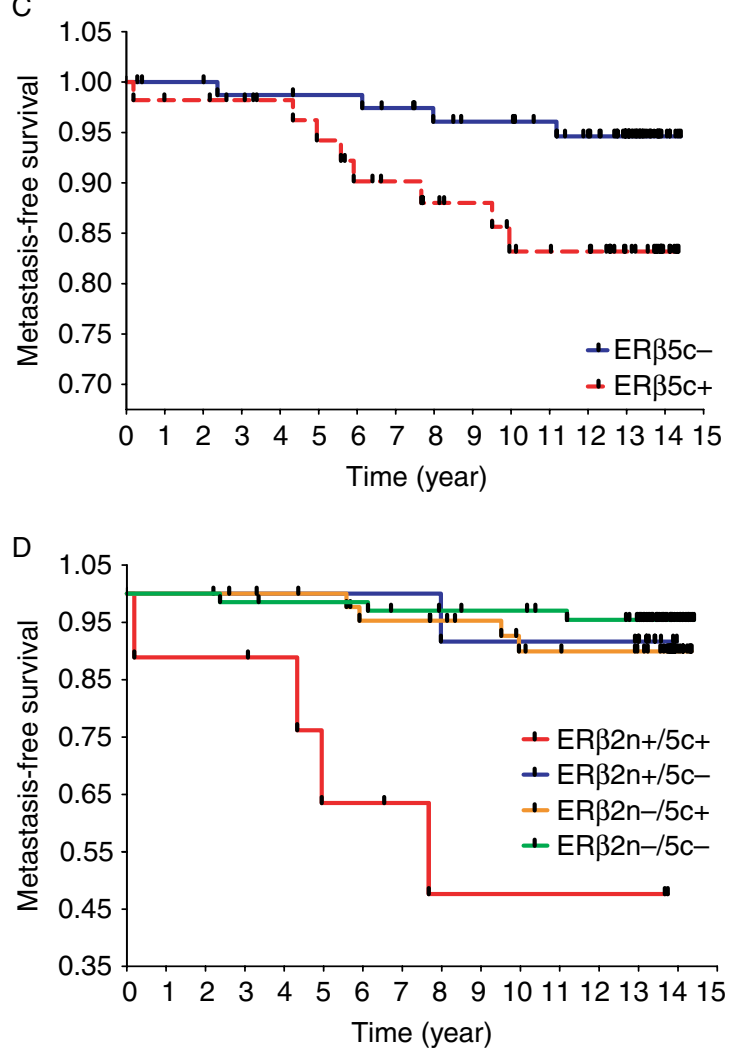

Results from this study serve as the first exploration to open a new line of investigation.

The action of estrogen in human normal and malignant prostatic tissue is believed to be mediated partly by ER $\beta$ because it is the predominant ER subtype in the prostate epithelium (Kuiper et al. 1996, Leav et al. 2001). However, the role of ER $\beta$ in prostate and breast cancers is still debatable, even after 10 years of extensive research (Ho et al. 2006). Data from different research groups conflict (Speirs et al. 2004, Skliris et al. 2006), in part because of insufficient understanding of ER $\beta$ isoforms that were discovered relatively recently (Leung et al. 2006) and the lack of antibodies to distinguish them in vitro and in clinical specimens. Unlike breast cancer research, in which the discovery of these molecules has stimulated new research directions (Speirs \& Walker 2007, Powell \& $\mathrm{Xu}$ 2008), similar developments in PCa research have been limited. The use of N-terminal-specific ER $\beta$ antibodies in IHC experiments is always problematic because they recognize all ER $\beta$ isoforms, and mRNA expression data clearly showed that each ER $\beta$ isoform has a unique, tissue- and cell type-specific expression pattern (Leung et al. 2006). This study is the first to provide data at the protein level illustrating this uniqueness in PCa. Our IHC staining revealed unique tissue-/cell type- and cellular compartment-specific distribution for each isoform in the normal and malignant prostate.

The functions of each isoform in the normal prostate epithelium are unclear. Thus, in this study, ER $\beta 1$ positivity was not associated with PCa progression, but the PC3 cell model suggested that ER $\beta 1$ inhibits both $\mathrm{PCa}$ cell migration and invasion, which is consistent with the current belief that ER $\beta$ is antiproliferative, tumor suppressive (Morani et al. 2008) and impedes epithelial-mesenchymal transition (Mak et al. 2010). However, others have suggested that ER $\beta$ is involved in an aggressive PCa phenotype (Horvath et al. 2001,

Figure 6 Evaluation of ER $\beta$ isoforms as a predictor for time to PSA failure and time to metastasis by the Kaplan-Meier (KM) plot with the log-rank test. The Allred cutpoint $(>3$ or $\leq 3)$ for each ER $\beta$ isoform was used to determine 'positive' and 'negative' expression. (A) KM plot of nuclear ER $\beta 2$ versus recurrence/PSA-free survival $(P<0.01)$. (B) KM plot of nuclear ERß2 versus metastasis-free survival $(P<0.01)$. (C) KM plot of cytoplasmic ER $\beta 5$ in metastasis-free survival $(P=0.03)$. (D) KM plot of nuclear ER $\beta 2$ and cytoplasmic ER $\beta 5$ versus metastasisfree survival $(P<0.01)$. Patients were further stratified into four groups according to status of ER $\beta$ isoform expression: i) both nuclear ER $\beta 2$ and cytoplasmic ER $\beta 5$ positive $(n=9)$; ii) nuclear ER $\beta 2$ positive and cytoplasmic ER $\beta 5$ negative $(n=12)$; iii) nuclear ER $\beta 2$ negative and cytoplasmic ER $\beta 5$ positive $(n=46)$; and iv) both nuclear ER $\beta 2$ and cytoplasmic ER $\beta 5$ negative $(n=68) . P<0.05$ was considered to be statistically significant. 

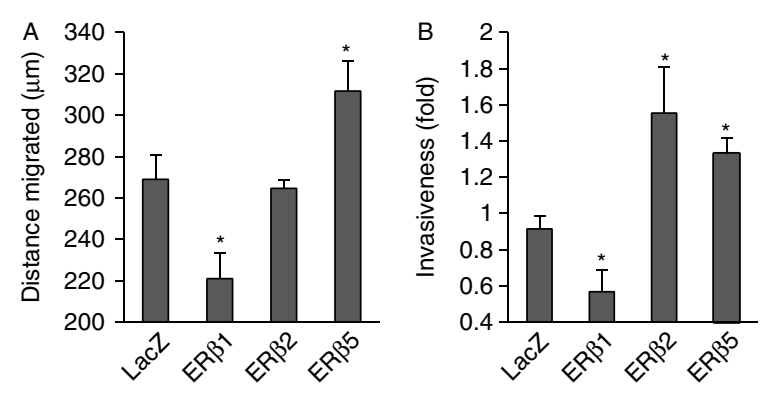

Figure 7 Tumor metastasis of PC3 expressing ER $\beta$ isoforms. (A) Results of wound-healing assay. Migration distance of PC3 expressing LacZ (as a control), ER $\beta 1$, ER $\beta 2$, and ER $\beta 5$ was recorded and calculated after $24 \mathrm{~h}$ of wound introduction. Experiments were carried out in triplicate and were repeated with three independent sets. Student's $t$-test was used to compare the mean distance migrated of each ER $\beta$ isoformexpressing cell line versus LacZ control cells (average \pm s.E.M., $\left.{ }^{*} P<0.05\right)$. (B) Results of Matrigel-based invasion assay. Fixed number $\left(5 \times 10^{4}\right)$ of cells was set up in a 24-well plate according to the manufacturer's recommendation. The cells that crossed the matrigel membrane were stained and counted under a microscope. Cell numbers were normalized by the MTS method. The fold invasiveness was calculated relative to the number of cells invaded in LacZ control. Experiments were carried out in triplicate and were repeated with three independent sets. Student's $t$-test was used to compare the fold invasiveness of each cell line versus LacZ control cells (average \pm S.E.M., ${ }^{\star} P<0.05$ ).

Nanni et al. 2009). We speculate that this kind of discrepancy will be resolved in the future by including $\mathrm{ER} \beta$ isoforms during data analysis. In this TMA study, $\mathrm{ER} \beta 2$, the most commonly expressed isoform $(>80 \%)$ in $\mathrm{PCa}$ cells, is primarily cytoplasmic, and its nuclear positivity correlates with $\mathrm{PF}, \mathrm{POM}$, and a shorter time to POM. These results are in agreement with a study with a smaller cohort analyzed with different clinical outcomes (Fujimura et al. 2001). However, this study was the first to investigate ER $\beta 5$ and its prognostic value in PCa. Both ER $\beta 2$ and ER $\beta 5$ elevated PCa cell invasion, but only the cells expressing ER $\beta 5$ migrated more rapidly. This suggests that ER $\beta 2$ and ER $\beta 5$ could regulate different tumor metastasis pathways in $\mathrm{PCa}$ cells, perhaps explaining why co-existence of ER $\beta 2$ and ER $\beta 5$ in PCa tissue could predict the worst clinical outcome, probably due to synergistic actions of ER $\beta 2$ and ER $\beta 5$ in PCa progression. Through the use of isoform-specific antibodies, we have gained new insights into the prognostic values of ER $\beta$ isoforms that will undoubtedly continue to increase our understanding of ER $\beta$ s in the development and progression of PCa. The utility of ER $\beta 2$ and ER $\beta 5$ as PCa prognostic markers is obviously worthy of further investigation.

Both isoforms have been found in various tissues (Pedersen et al. 2001, Scobie et al. 2002, Poola 2003,
Cammarata et al. 2005, Wong et al. 2005), including the prostate (Leung et al. 2006). The functions of these isoforms are not yet clear, but they are known to be involved in ER $\alpha$ (Peng et al. 2003, Poola et al. 2005) and ER $\beta 1$ signaling (Leung et al. 2006). At the molecular level, either ER $\beta 2$ or ER $\beta 5$ by itself does not transactivate ERE-driven promoter but when heterodimerized with ER $\beta 1$ can alter its transactivation activity (Leung et al. 2006). The roles of ER $\beta 2$ and ER $\beta 5$ in cancer were not studied until recently. Their nuclear expression in breast cancer tissue was significantly correlated with better overall survival (Shaaban et al. 2008), a finding that differs from our data showing a significant correlation between ER $\beta 2 / E R \beta 5$ positivity in PCa cells and poor POMfree survival. This discrepancy suggests a fundamental difference in the role played by estrogens/estrogen signaling in the pathogenesis of $\mathrm{PCa}$ versus that of breast cancer, which has introduced an intriguing question regarding the clinical management of these cancers.

We recognize that our cohort is small (144 patients) compared with that of the breast cancer study (Shaaban et al. 2008) and thus includes relatively few patients with PF $(n=54 ; \geq 2 \mathrm{ng} / \mathrm{ml})$ and POM $(n=12)$. However, the possibility of using ER $\beta 2$ and ER $\beta 5$ for PCa prognosis shows great promise, partly because of the long lead-time before postoperative PF (6.2 years) and time to POM (8.6 years). Therefore, the confirmation of ER $\beta 2$, in conjunction ER $\beta 5$ or other established markers, as an independent prognostic marker in future cohort studies, could help to identify candidates for clinical trials of new interventions designed to curb PCa progression based on information gained at the time of radical prostatectomy from IHC analysis for ERßs. Moreover, more active surveillance and/or adjuvant therapies, such as external beam radiotherapy and ADTs (Michaelson et al. 2008, Wirth et al. 2008), may be indicated for the subset of patients at higher risk for metastases because of their positivity for ER $\beta 2$ and ER $\beta 5$.

Mechanistic studies aimed at elucidating the biological roles of ER $\beta$ s require relevant cell model systems. Cammarata et al. (2005) were the first to report different subcellular localizations of ER $\beta$ isoforms in breast cancer cells. In a PCa cell line (PC3), $\mathrm{ER} \beta 1$ resides mostly in the nucleus. Although very few ER $\beta 1$ molecules were detected in cytoplasm, they were not localized in the mitochondria in this PCa cell line, a finding different from other published cell data (Chen et al. 2004). Both ER $\beta 2$ and ER $\beta 5$ were localized in both cytoplasmic and nuclear compartments in PC3 cells. It is not clear whether such unique patterns of 
subcellular localizations of ER $\beta$ isoforms in PCa cells are related to their metastasis-promoting functions or simply to differential protein trafficking and/or processing. Those are the questions worthy of further investigation. As a caveat, it is almost certain that there are no perfect cell model systems that could fully recapitulate the in vivo situation, whereby epithelial cells are surrounded by different types of stromal cells in a three-dimensional architecture. Thus, interpretations of data from cell model systems would best be supported by parallel correlative studies of human tissues.

In conclusion, in a group of PCa patients with relatively long follow-up, our data demonstrate that expression of ER $\beta 2$ in the nucleus of PCa cells is an independent prognostic marker of PF, POM, and time to POM, and cER $\beta 5$ positivity predicts shorter POMfree survival. Additionally, the expression of both nER $\beta 2$ and cER $\beta 5$ identified a group of patients with the worst clinical outcome. Finally, forced expression of ER 32 or ER $\beta 5$ in PC3 cells uncovered that these isoforms have metastasis-promoting action, supporting our IHC findings. Given the long duration of time to $\mathrm{PF} / \mathrm{POM}$, prognostic markers such as these should help in stratifying patients in clinical trials and in devising more effective customized therapies for advanced PCa.

\section{Declaration of interest}

The authors declare that there is no conflict of interest that could be perceived as prejudicing the impartiality of the research reported.

\section{Funding}

This work was supported by grants from NIH (ES006096, CA15776, and CA112532 to S-M Ho), the Bertucci Foundation of Prostate Cancer Research (to C-L Wu), and the US Army Prostate Cancer Program (81XWH-04-1-0165 to S-M Ho), and an internal funding source from the University of Cincinnati Medical Center.

\section{Acknowledgements}

We thank Dr Neville Tam, Dr Olivia Lee, and Mr Prashant Angiah Srikanthan in the Department of Environmental Health, University of Cincinnati Medical Center for their excellent technical support and Nancy Voynow for her professional editing of this manuscript.

\section{References}

Adams JY, Leav I, Lau KM, Ho SM \& Pflueger SM 2002 Expression of estrogen receptor beta in the fetal, neonatal, and prepubertal human prostate. Prostate 52 69-81.
Allred DC, Clark GM, Elledge R, Fuqua SA, Brown RW, Chamness GC, Osborne CK \& McGuire WL 1993 Association of p53 protein expression with tumor cell proliferation rate and clinical outcome in node-negative breast cancer. Journal of the National Cancer Institute $\mathbf{8 5}$ 200-206.

Antal MC, Krust A, Chambon P \& Mark M 2008 Sterility and absence of histopathological defects in nonreproductive organs of a mouse ERbeta-null mutant. PNAS $\mathbf{1 0 5}$ 2433-2438.

Cammarata PR, Flynn J, Gottipati S, Chu S, Dimitrijevich S, Younes M, Skliris G \& Murphy LC 2005 Differential expression and comparative subcellular localization of estrogen receptor beta isoforms in virally transformed and normal cultured human lens epithelial cells. Experimental Eye Research 81 165-175.

Chen JQ, Delannoy M, Cooke C \& Yager JD 2004 Mitochondrial localization of ERalpha and ERbeta in human MCF7 cells. American Journal of Physiology. Endocrinology and Metabolism 286 E1011-E1022.

Couse JF, Curtis HS \& Korach KS 2000 Receptor null mice reveal contrasting roles for estrogen receptor alpha and beta in reproductive tissues. Journal of Steroid Biochemistry and Molecular Biology 74 287-296.

Culig Z \& Bartsch G 2006 Androgen axis in prostate cancer. Journal of Cellular Biochemistry 99 373-381.

Dehm SM, Schmidt LJ, Heemers HV, Vessella RL \& Tindall DJ 2008 Splicing of a novel androgen receptor exon generates a constitutively active androgen receptor that mediates prostate cancer therapy resistance. Cancer Research 68 5469-5477.

Dupont S, Krust A, Gansmuller A, Dierich A, Chambon P \& Mark M 2000 Effect of single and compound knockouts of estrogen receptors alpha (ERalpha) and beta (ERbeta) on mouse reproductive phenotypes. Development 127 4277-4291.

Eisen M, Napp HE \& Vock R 1975 Inhibition of platelet aggregation caused by estrogen treatment in patients with carcinoma of the prostate. Journal of Urology 114 93-97.

Ellem SJ \& Risbridger GP 2009 The dual, opposing roles of estrogen in the prostate. Annals of the New York Academy of Sciences 1155 174-186.

Ellem SJ, Schmitt JF, Pedersen JS, Frydenberg M \& Risbridger GP 2004 Local aromatase expression in human prostate is altered in malignancy. Journal of Clinical Endocrinology and Metabolism 89 2434-2441.

Epstein JI, Allsbrook WC Jr, Amin MB \& Egevad LL 2005 The 2005 International Society of Urological Pathology (ISUP) Consensus Conference on Gleason Grading of Prostatic Carcinoma. American Journal of Surgical Pathology 29 1228-1242.

Fujimura T, Takahashi S, Urano T, Ogawa S, Ouchi Y, Kitamura T, Muramatsu M \& Inoue S 2001 Differential expression of estrogen receptor beta (ERbeta) and its C-terminal truncated splice variant ERbetacx as prognostic predictors in human prostatic cancer. Biochemical and Biophysical Research Communications 289 692-699. 
Guo Z, Yang X, Sun F, Jiang R, Linn DE, Chen H, Chen H, Kong X, Melamed J, Tepper CG et al. 2009 A novel androgen receptor splice variant is up-regulated during prostate cancer progression and promotes androgen depletion-resistant growth. Cancer Research 69 2305-2313.

Hanash KA, Taylor WF, Greene LF, Kottke BA \& Titus JL 1970 Relationship of estrogen therapy for carcinoma of the prostate to atherosclerotic cardiovascular disease: a clinicopathologic study. Journal of Urology 103 467-470.

Heldring N, Pike A, Andersson S, Matthews J, Cheng G, Hartman J, Tujague M, Strom A, Treuter E, Warner M et al. 2007 Estrogen receptors: how do they signal and what are their targets. Physiological Reviews 87 905-931.

Henderson BE, Bernstein L, Ross RK, Depue RH \& Judd HL 1988 The early in utero oestrogen and testosterone environment of blacks and whites: potential effects on male offspring. British Journal of Cancer 57 216-218.

Ho SM, Leung YK \& Chung I 2006 Estrogens and antiestrogens as etiological factors and therapeutics for prostate cancer. Annals of the New York Academy of Sciences 1089 177-193.

Horvath LG, Henshall SM, Lee CS, Head DR, Quinn DI, Makela S, Delprado W, Golovsky D, Brenner PC, O’Neill G et al. 2001 Frequent loss of estrogen receptor-beta expression in prostate cancer. Cancer Research $615331-5335$.

Huggins C \& Hodges CV 2002 Studies on prostatic cancer: I. The effect of castration, of estrogen and of androgen injection on serum phosphatases in metastatic carcinoma of the prostate. 1941. Journal of Urology 168 9-12.

Jemal A, Siegel R, Ward E, Hao Y, Xu J \& Thun MJ 2009 Cancer Statistics, 2009. CA: A Cancer Journal for Clinicians 59 225-249.

Krege JH, Hodgin JB, Couse JF, Enmark E, Warner M, Mahler JF, Sar M, Korach KS, Gustafsson JA \& Smithies O 1998 Generation and reproductive phenotypes of mice lacking estrogen receptor beta. PNAS 95 15677-15682.

Kuiper GG, Enmark E, Pelto-Huikko M, Nilsson S \& Gustafsson JA 1996 Cloning of a novel receptor expressed in rat prostate and ovary. PNAS 93 5925-5930.

Lai JS, Brown LG, True LD, Hawley SJ, Etzioni RB, Higano CS, Ho SM, Vessella RL \& Corey E 2004 Metastases of prostate cancer express estrogen receptor-beta. Urology 64 814-820.

Langley RE, Godsland IF, Kynaston H, Clarke NW, Rosen SD, Morgan RC, Pollock P, Kockelbergh R, Lalani el-N, Dearnaley D et al. 2008 Early hormonal data from a multicentre phase II trial using transdermal oestrogen patches as first-line hormonal therapy in patients with locally advanced or metastatic prostate cancer. BJU International 102 442-445.

Leav I, Ho SM, Ofner P, Merk FB, Kwan PW \& Damassa D 1988 Biochemical alterations in sex hormone-induced hyperplasia and dysplasia of the dorsolateral prostates of Noble rats. Journal of the National Cancer Institute $\mathbf{8 0}$ 1045-1053.
Leav I, Lau KM, Adams JY, McNeal JE, Taplin ME, Wang J, Singh H \& Ho SM 2001 Comparative studies of the estrogen receptors beta and alpha and the androgen receptor in normal human prostate glands, dysplasia, and in primary and metastatic carcinoma. American Journal of Pathology 159 79-92.

Leung YK, Mak P, Hassan S \& Ho SM 2006 Estrogen receptor (ER)-beta isoforms: a key to understanding ER-beta signaling. PNAS 103 13162-13167.

Mak P, Leav I, Pursell B, Bae D, Yang X, Taglienti CA, Gouvin LM, Sharma VM \& Mercurio AM 2010 ERbeta impedes prostate cancer EMT by destabilizing HIF1alpha and inhibiting VEGF-mediated snail nuclear localization: implications for Gleason grading. Cancer Cell 17 319-332.

Matzkin H \& Soloway MS 1992 Immunohistochemical evidence of the existence and localization of aromatase in human prostatic tissues. Prostate 21 309-314.

Michaelson MD, Cotter SE, Gargollo PC, Zietman AL, Dahl DM \& Smith MR 2008 Management of complications of prostate cancer treatment. CA: A Cancer Journal for Clinicians 58 196-213.

Moore JT, McKee DD, Slentz-Kesler K, Moore LB, Jones SA, Horne EL, Su JL, Kliewer SA, Lehmann JM \& Willson TM 1998 Cloning and characterization of human estrogen receptor beta isoforms. Biochemical and Biophysical Research Communications 247 75-78.

Morani A, Warner M \& Gustafsson JA 2008 Biological functions and clinical implications of oestrogen receptors alfa and beta in epithelial tissues. Journal of Internal Medicine 264 128-142.

Nanni S, Benvenuti V, Grasselli A, Priolo C, Aiello A, Mattiussi S, Colussi C, Lirangi V, Illi B, D'Eletto M et al. 2009 Endothelial NOS, estrogen receptor beta, and HIFs cooperate in the activation of a prognostic transcriptional pattern in aggressive human prostate cancer. Journal of Clinical Investigation 119 1093-1108.

Ockrim J, Lalani el-N \& Abel P 2006 Therapy insight: parenteral estrogen treatment for prostate cancer - a new dawn for an old therapy. Nature Clinical Practice \& Oncology 3 552-563.

Pais V, Leav I, Lau KM, Jiang Z \& Ho SM 2003 Estrogen receptor-beta expression in human testicular germ cell tumors. Clinical Cancer Research 9 4475-4482.

Pedersen SB, Bruun JM, Hube F, Kristensen K, Hauner H \& Richelsen B 2001 Demonstration of estrogen receptor subtypes alpha and beta in human adipose tissue: influences of adipose cell differentiation and fat depot localization. Molecular and Cellular Endocrinology 182 27-37.

Peng B, Lu B, Leygue E \& Murphy LC 2003 Putative functional characteristics of human estrogen receptor-beta isoforms. Journal of Molecular Endocrinology 30 13-29.

Poola I 2003 Molecular assays to profile 10 estrogen receptor beta isoform mRNA copy numbers in ovary, breast, uterus, and bone tissues. Endocrine 22 101-112. 
Poola I, Abraham J, Baldwin K, Saunders A \& Bhatnagar R 2005 Estrogen receptors beta4 and beta5 are full length functionally distinct ERbeta isoforms: cloning from human ovary and functional characterization. Endocrine 27 227-238.

Powell E \& Xu W 2008 Intermolecular interactions identify ligand-selective activity of estrogen receptor alpha/beta dimers. PNAS 105 19012-19017.

Prins GS 1997 Developmental estrogenization of the prostate gland. In Prostate: Basic and Clinical Aspects, ch 10, pp 247-263. Ed. KN Rajesh. Boca Raton, FL: CRC Press Inc.

Prins GS \& Korach KS 2008 The role of estrogens and estrogen receptors in normal prostate growth and disease. Steroids 73 233-244.

Prins GS, Birch L, Tang WY \& Ho SM 2007 Developmental estrogen exposures predispose to prostate carcinogenesis with aging. Reproductive Toxicology 23 374-382.

Ricke WA, McPherson SJ, Bianco JJ, Cunha GR, Wang Y \& Risbridger GP 2008 Prostatic hormonal carcinogenesis is mediated by in situ estrogen production and estrogen receptor alpha signaling. FASEB Journal 22 1512-1520.

Rodriguez LG, Wu X \& Guan JL 2005 Wound-healing assay. Methods in Molecular Biology 294 23-29.

Rohrmann S, Nelson WG, Rifai N, Brown TR, Dobs A, Kanarek N, Yager JD \& Platz EA 2007 Serum estrogen, but not testosterone, levels differ between black and white men in a nationally representative sample of Americans. Journal of Clinical Endocrinology and Metabolism 92 2519-2525.

Schally AV, Redding TW \& Comaru-Schally AM 1983 Inhibition of prostate tumors by agonistic and antagonistic analogs of LH-RH. Prostate 4 545-552.

Scher HI, Buchanan G, Gerald W, Butler LM \& Tilley WD 2004 Targeting the androgen receptor: improving outcomes for castration-resistant prostate cancer. Endocrine-Related Cancer 11 459-476.

Scobie GA, Macpherson S, Millar MR, Groome NP, Romana PG \& Saunders PT 2002 Human oestrogen receptors: differential expression of ER alpha and beta and the identification of ER beta variants. Steroids $\mathbf{6 7}$ 985-992.

Shaaban AM, Green AR, Karthik S, Alizadeh Y, Hughes TA, Harkins L, Ellis IO, Robertson JF, Paish EC, Saunders PT et al. 2008 Nuclear and cytoplasmic expression of
ERbeta1, ERbeta2, and ERbeta5 identifies distinct prognostic outcome for breast cancer patients. Clinical Cancer Research 14 5228-5235.

Skliris GP, Leygue E, Curtis-Snell L, Watson PH \& Murphy LC 2006 Expression of oestrogen receptor-beta in oestrogen receptor-alpha negative human breast tumours. British Journal of Cancer 95 616-626.

Speirs V \& Walker RA 2007 New perspectives into the biological and clinical relevance of oestrogen receptors in the human breast. Journal of Pathology 211 499-506.

Speirs V, Carder PJ, Lane S, Dodwell D, Lansdown MR \& Hanby AM 2004 Oestrogen receptor beta: what it means for patients with breast cancer. Lancet Oncology 5 174-181.

Stone NN, Fair WR \& Fishman J 1986 Estrogen formation in human prostatic tissue from patients with and without benign prostatic hyperplasia. Prostate 9 311-318.

Takase Y, Levesque MH, Luu-The V, El Alfy M, Labrie F \& Pelletier G 2006 Expression of enzymes involved in estrogen metabolism in human prostate. Journal of Histochemistry and Cytochemistry 54 911-921.

Weihua Z, Makela S, Andersson LC, Salmi S, Saji S, Webster JI, Jensen EV, Nilsson S, Warner M \& Gustafsson JA 2001 A role for estrogen receptor beta in the regulation of growth of the ventral prostate. PNAS $\mathbf{9 8}$ 6330-6335.

Wirth MP, Hakenberg OW \& Froehner M 2008 Adjuvant hormonal treatment - the bicalutamide early prostate cancer program. Frontiers of Radiation Therapy and Oncology 41 39-48.

Wong NA, Malcomson RD, Jodrell DI, Groome NP, Harrison DJ \& Saunders PT 2005 ERbeta isoform expression in colorectal carcinoma: an in vivo and in vitro study of clinicopathological and molecular correlates. Journal of Pathology 207 53-60.

Zhang X, Leung YK \& Ho SM 2007 AP-2 regulates the transcription of estrogen receptor (ER)-beta by acting through a methylation hotspot of the $0 \mathrm{~N}$ promoter in prostate cancer cells. Oncogene $\mathbf{2 6}$ 7346-7354.

Zhu X, Leav I, Leung YK, Wu M, Liu Q, Gao Y, McNeal JE \& Ho SM 2004 Dynamic regulation of estrogen receptorbeta expression by DNA methylation during prostate cancer development and metastasis. American Journal of Pathology 164 2003-2012. 